\title{
The Impact of Cultural Knowledge on Listening Comprehension
}

\section{of EFL Learners}

\author{
A. Majid Hayati \\ Dept. of English, College of Lit. \& Humanities \\ Shahid Chamran University, Iran \\ E-mail: majid_hayati@yahoo.com
}

\begin{abstract}
The aim of the present study was to investigate the effect of cultural knowledge on improving Iranian EFL learners' listening comprehension. To achieve this purpose, out of three hundred participants, one hundred and twenty pre-intermediate language learners were selected based on their scores on a listening comprehension test and were randomly assigned to four groups. Each group was exposed to a certain condition as follows: TC (Target Culture), ITC (International Target Culture), SC (Source Culture), and CF (Culture Free). At the end of the experiment, to see whether or not any changes happened regarding their listening proficiency, a post-test was administered to the four groups. The results suggested that the participants performed differently on the post-test indicating that familiarity with culturally-oriented language material promotes the Iranian EFL learners' listening proficiency.
\end{abstract}

Keywords: Listening comprehension, Cultural knowledge, L2 listeners, EFL learners, Source culture, Target culture

\section{Introduction}

Foreign language listening comprehension is a complex process and crucial in the development of foreign language competence; yet, the importance of listening in language learning has only been recognized relatively recently (Celce-Murcia, 2001; Rost, 2002). Since the role of listening comprehension in language learning was either overlooked or undervalued, it merited little research and pedagogical attention in the past. But at present, some researchers have devoted some time to listening and believe it to be an important skill in teaching and learning. For instance, Nunan (1998) believes that, "listening is the basic skill in language learning. Without listening skill, learners will never learn to communicate effectively. In fact over $50 \%$ of the time that students spend functioning in a foreign language will be devoted to listening" (p. 1).

However, careful observation of school English teaching practice has found that the teaching of listening skills is still the weak link in the language teaching process. Despite students having mastered the basic elements of English grammar and vocabulary, their listening comprehension is often weak. Through systematic study of basic English teaching stages at university, it has been recognized that while students' integrated skills in reading, writing and translating, have been improving, their listening and speaking capabilities have been left behind. The key factor that has been recognized in the preliminary studies is students' limited listening comprehension.

One aspect of language processing widely held as supporting and enhancing comprehension is that of mental schemata. Research in reading supports the notion that activating prior knowledge or knowledge of the world and applying this knowledge to new input greatly facilitates processing and understanding (Graves \& Cook, 1980). Listening, like reading, is an active process that entails construction of meaning beyond simple decoding. Activation of what is known about the world clearly assists processing the aural code.

Having a good listening comprehension skill has always been the main concern of not only EFL students, but also their teachers who want to teach English in the authentic context especially for communicative purposes. From the very moment that EFL students start learning English as a foreign language in school, what comes to their minds after listening to the native speaker's speech is to comprehend all the speech which is heard.

More specifically, language carries knowledge and cultural information and it reflects the substantial and particular ways of thinking of that people. Thus culture is embedded in even the simplest act of language (Hao, 2000; Kramsch, 1993); it is an inseparable part of the way in which we live our lives and the way we use language. In this regard, Kramsch (1993) maintains that every time we speak we perform a cultural act. Consequently, there is now, an emphasis in modern language teaching on cultural knowledge as a basis for language learning. An important requirement, then, for learning spoken English, is the acquisition of cultural knowledge. Therefore, if students' pronunciation, grammar, vocabulary and cultural knowledge are to prosper, they must be grounded in a sound knowledge of the society in which the language is based. 
As Cook (2003) points out:

The successful interpretation of language (spoken or written) in context depends upon the degree to which the participants share conventions and procedures, including those related to paralanguage. Such conventions and procedures, together with the values and beliefs behind them, are elements of cultural background knowledge... (p. 52).

The integral relationship between language and culture has led to numerous debates on the role and impact of English language teaching in general and of English language programs in Iran in particular. Ranging from English linguistic imperialism and cultural invasion to cultural neutrality, the interpretations of the state of culture in ELT in Iran is still controversial. According to Aliakbari (2004), in particular, two extreme evaluations of ELT appear in the agenda. On the one hand, English culture as a school subject is seen as representing and introducing western culture to the Iranian students. On the other hand, there are voices postulating that English culture as it is presently taught in Iran is nothing but a representation of the Persian or Islamic ideology. This unresolved controversy prompted many recent investigations into the cultural content of ELT in Iran.

\section{Review of Literature}

Listening has long been the neglected skill in second language acquisition, research, teaching, and assessment. However, in recent years there has been an increased focus on L2 listening ability because of its perceived importance in language learning and acquisition. Few empirical studies have explored the potential relationship between prior knowledge and listening comprehension. Mueller (1980) investigated the effects of background knowledge on listening comprehension of locus of contextual visuals for different levels of aptitude of beginning college German students. The aptitude variable consisted of two levels (high and low) determined by the participants' grades in the preceding German course. He found that the students who had the contextual visual before hearing the passage scored significantly higher on the recall measure than those in the visual-after and the no-visual groups.

In order to determine the influence of religion-specific background knowledge on the listening comprehension of ESL students, Markham and Latham (1987) used passages describing prayer rituals of Islam and Christianity. The data indicated that religious background influences listening comprehension. The subjects in this study recalled more information and provided more elaborations and fewer distortions for the passage that related to their own religion.

Long (1990) conducted an exploratory study of background knowledge and L2 listening comprehension. Her third-quarter students of Spanish listened to two passages, one familiar and the other unfamiliar. Comprehension was assessed by a recall protocol in English, a recognition measure, and a checklist comprised of true-false statements referring to the content of the passage. Although the English summaries revealed a higher proportion of correct idea units for the familiar topic, no significant differences were found between the familiar and unfamiliar passages in the recognition measure.

Bacon (1992), conducting an experiment with Spanish students, investigated strategies used in three identified phases: perceptual, parsing, and utilization. After listening to two expository passages selected from Voice of America broadcast, her subjects reported their strategy use and comprehension in an interview situation. Regarding background knowledge, she found little use of advance organizers during the perceptual phase, but effective use of previous knowledge during the utilization phase. She reported that successful listeners tended to use their personal, world, and discourse knowledge while less successful listeners either built erroneous meaning from their prior knowledge or ignored it altogether.

To help teachers discover effective strategies appropriate for ethnic minority students, another study was conducted by Ervin (1992) to see whether listeners better understand material related to their own culture, and whether thematic units are an effective method for building culturally related schemata. Within a pre- and posttest design, a class of 25 Scottish pupils and a class of 21 Texan students (ages 8 to 10 years) listened to a same-culture passage and answered a 10-item multiple-choice test. The groups then listened to another-culture passage and answered a similar test. Students/pupils participated in a one-week other-culture thematic unit and took the other-culture test. T-tests showed no significant difference between same-culture and other-culture pretest scores for the Texan group, but the Scottish group scored significantly higher on the same-culture test than the other-culture test.

Schmidt-Rinehart (1994) also carried out a study with the main purpose of discovering the effects of topic familiarity on L2 listening comprehension. University students of Spanish at three different course levels listened to two familiar passages, one about a familiar topic and another about a novel topic. The passages represented authentic language in that the recordings were from spontaneous speech of a native speaker. The results indicated that the subjects scored considerably higher on the familiar topic than on the new one (see also Caplan-Carbin, 1997).

Sadighi and Zare (2002), in their study, explored the effect of background knowledge on listening comprehension. Two TOEFL preparation classes allocated to EFL students took part in the study. The experimental group received some treatment in the form of topic familiarity, and their background knowledge was activated. Then a 50-item TOEFL test of 
listening comprehension was administered to both experimental and control groups. A statistical analysis of the results provides some evidence in support of the effect of background knowledge on listening comprehension.

Later, Othman and Vanathas (2004) also conducted an experiment that focused on topic familiarity and its influence on listening comprehension. Data were elicited from thirty four intermediate level students who were majoring in Business Studies at a private tertiary institution. A comparison between the pretest and posttest scores showed that the subjects achieved significantly higher marks after the treatment lessons. The findings of this study indicated that topic familiarity has an influence on listening comprehension.

Role of culture in language learning and teaching was investigated by Genc and Bada (2005). This study was conducted with the participation of the students of the ELT department of Çukurova University in Turkey. As a result of the study, a significant similarity between the students' views and the theoretical benefits of a culture class as argued by some experts in the field was observed. Regarding the benefits of learning about culture, attending the culture class has raised cultural awareness in ELT students concerning both native and target societies. This study illustrates how arguments of language teaching experts in favor of a culture class in language learning and teaching are justified by some sound evidence provided by the participants of this study.

In another study, the effects of cultural instruction on foreign language learning were investigated by Tsou (2005). For this purpose, the combination of an anthropology process and task-oriented approach was applied to conduct the cultural lessons. Culture instruction was implemented within two elementary EFL classrooms for one semester to see the effects of culture instruction on foreign language learning. When culture lessons were integrated into EFL instruction, students' language proficiency was significantly improved. In addition, they had better interests in language learning.

\section{Statement of the Problem}

According to Sadighi and Zare (2002), listening has been the neglected skill in foreign language acquisition, research, teaching, and assessment. However, in recent years there has been an increased focus on foreign language listening ability because of its perceived importance in language learning and acquisition.

It is the aim of many EFL students, in Iran, to listen to different taped materials or participate in extracurricular teaching programs such as communicating with native speakers of English, listening to English radio programs, watching English movies, etc. However, despite their appeal to different means, they might not gain as much as they desire.

According to Aliakbari (2004), the cultural content of the ELT in Iran has never been explicitly discussed. There is the serious absence of studies that examine the quality and the types of listening comprehension texts used in relation to cultural knowledge. Therefore, the major purpose motivating this study is to find out, whether the available listening comprehension texts provide sufficient context for students' understanding and make them ready for intercultural communication. More specifically, this study is motivated to investigate the relationship between cultural background knowledge and listening comprehension of Iranian EFL learners.

\section{Research Questions}

The present study seeks to answer the following questions:

1) Does familiarity with the target culture (English and American) affect Iranian EFL learners listening comprehension?

2) Does familiarity with international target culture (culture of different foreign countries such as Japan, China and India) affect Iranian EFL learners listening comprehension?

3) Does familiarity with Persian culture (source culture) affect Iranian EFL learners listening comprehension?

4) Do culture free materials have any effect on Iranian EFL learners' listening comprehension?

\section{Research Hypotheses}

The purpose of the present study is to reveal the effect of cultural familiarity on the Iranian EFL students' listening comprehension. The result will, therefore, shed lights on the following hypotheses:

H01. Materials with the target language (English and American) culture orientation do not have any significant influence on the listening comprehension of Iranian EFL learners.

H02. Materials with international culture orientation do not have any significant influence on the listening comprehension of Iranian EFL learners.

H03. Materials with Persian culture orientation do not have any significant influence on the listening comprehension of Iranian EFL learners.

H04. Culture-free materials do not have any significant influence on the listening comprehension of Iranian EFL learners. 


\section{Methodology \\ 6.1 Participants}

For the present study, out of three hundred students learning English at two private language institutions of Andimeshk, a city in the south of Iran, a hundred and twenty participants (both male and female) with the age range of 13-25 were selected based on a proficiency test.

\subsection{Instruments}

The following instruments were used in the study:

1) First, a listening comprehension test containing 25 multiple-choice items was extracted from Test of English as a Foreign Language (Sharpe, 2001). The reliability of the test was .732 based on KR-21 method.

2) Second, there were materials selected from Internet reliable sites (such as bbc.com and cnn.com) and other authentic sources such as New Interchange Series (Richards, 2005). In order to account for the influence of culture on listening comprehension, four types of materials reflecting different cultures were proposed: English and American culture, international target culture, Persian culture and culture-free.

\section{Procedures}

First, the proficiency test (Sharpe, 2001) was given to three hundred EFL learners including both males and females of two private language institutions in Andimeshk. Calculating the scores, 120 participants who scored between 36 and 64 out of 100 in the proficiency test (two standard deviations above and below the mean) were selected as pre-intermediate language learners; later, based on systematic random sampling, they were divided into four groups: group A (Target Culture $=\mathrm{TC}$ ), group B (International Target Culture $=\mathrm{ITC}$ ), group C (Source Culture $=\mathrm{SC}$ ) and group D (Culture-Free $=\mathrm{CF}$ ). Over the course of 10 weeks ( 40 hours), classes were conducted two times a week by an experienced teacher in the private language school. The participants in each group practiced listening comprehension materials that reflected a particular culture. Finally, the four groups took a listening comprehension test which included sample authentic listening comprehension materials as mentioned earlier in this paper. The scores obtained by the four groups were compared with one another to see whether or not there were possible differences between groups in their listening comprehension test.

\section{Results}

\section{The analysis of variance of participants' post-test scores in four groups}

Tables 1 and 2 illustrate the mean scores gained by each group in the pre-test and post-test respectively. As is observed, the participants who listened to the culturally-oriented materials scored higher than the other three groups.

\section{Insert Table 1 right about here.}

\section{Insert Table 2 right about here.}

An analysis of variance (ANOVA) found the scores on the four groups in post-tests to be significantly different. Since the F-ratio is bigger than 1, we know that there is a meaningful difference among the means. In the same vein, to pinpoint the precise location of any statistically significant differences between four groups, the researcher calculated a dependent t-test. Additionally, post-hoc dependent t- tests indicated that, in regard to the effect of cultural background knowledge, the performance of all groups differed significantly $(\mathrm{p}<0.001)$. The differences between the mean scores of groups $A$ and $B(d=.73)$ were lower than the differences between groups $A$ and $D(d=4.3)$. In the same line, the differences between the mean scores of $A$ and $B(d=.73)$ appeared to be lower than $B$ and $D(d=3.57)$, and $A$ and $C(d=$ 1.36) lower than $C$ and $D(d=2.94)$. On the other hand, the difference between the mean scores of groups $B$ and $C(d$ $=.63)$ was lower than that of groups $\mathrm{B}$ and $\mathrm{D}(\mathrm{d}=3.57)$ and groups $\mathrm{C}$ and $\mathrm{D}(\mathrm{d}=2.94)$. The results of One-Way ANOVA Test point out that the mean values of the treatment groups gained in the study are not the same.

\section{Insert Table 3 right about here.}

\section{The results of group $A(T C)$}

Regarding group A performance, there was a significant difference between the participants' mean scores in the pretest and the posttest. In order to make sure that the difference in the mean scores was statistically significant, the statistical t-test was administered. For group A, the t-observed was calculated as 4.02 for a degree of freedom of 58 which was higher than the t-critical of 1.671. The results, therefore, confirmed that group A of the participants performed differently in the two tests. In other words, the difference between the mean scores of group A (TC) is statistically significant $(\mathrm{P}<0.01$, $\mathrm{t}$-value $=4.02)$. This shows that the participants in TC group performed better in the test and this better performance seems to be the result of their familiarity with the culturally-oriented materials which was fulfilled during the instruction period of the study. So the participants in group A could improve their listening comprehension 
during the semester through having greater exposure to target culture texts as one kind of specific culturally-oriented language listening materials.

\section{Insert Table 4 right about here.}

According to the above mentioned information, as the critical value of group one (TC) was 1.671 indicating a significant difference between the observed $\mathrm{T}$ and the critical T, therefore, $\mathrm{H} 01$ emphasizing that texts with English and American culture orientation do not have any significant influence on the listening comprehension of Iranian EFL learners was safely rejected.

The results of group B (ITC)

Regarding the performance of group two (ITC), there was a significant difference between the participants' mean scores in the pretest and the posttest. In order to make sure that the difference in the mean scores was statistically significant, the statistical t-test was administered. The t-observed was calculated as 3.30 for a degree of freedom of 58 which was higher than the t-critical of 1.671. The results, therefore, confirmed that group two (ITC) of the participants performed differently in the two tests. In other words, as table 5 indicates, the difference between the mean scores is statistically significant $(\mathrm{P}<0.01, \mathrm{t}$-value $=3.30)$. This shows that the participants in ITC group performed better than the other groups ( $\mathrm{SC}$ and $\mathrm{CF}$ ) in the test.

\section{Insert Table 5 right about here.}

Results of group C (SC)

Regarding group C (SC), there was a significant difference between mean scores in the pretest and the posttest. Again, since the t-observed (3.42) was higher than t-critical (1.67), it is confirmed that group C participants performed differently in the two tests. As table 6 indicates, the difference between the mean scores of participants in SC group is statistically significant $(\mathrm{P}<0.01, \mathrm{t}$-value $=3.42)$. This shows that the participants in group $\mathrm{C}$ could improve their listening comprehension during the semester through having exposure to source culture texts as one kind of specific culturally-oriented language listening materials.

\section{Insert Table 6 right about here.}

\section{The results of group $D(C F)$}

There was not any significant difference between the mean scores of group D in the pretest and the posttest. As shown in table 7, the t-observed was calculated as .55 which was less than the t-critical (1.671). The results, therefore, confirmed that group four participants performed nearly the same in the two tests $(\mathrm{P}<0.01$, $t$-value $=.55)$. This shows that the participants in CF group failed to improve their listening comprehension during the semester through having exposure to culture free texts.

\section{Insert Table 7 right about here.}

Since t-critical (1.67) was lower than the t-observed in groups B (3.30), and C (3.42), the two hypotheses (H02 and H03) were rejected. But, as it is clear from the above tables, the t-critical (1.671) of group D was higher than the observed $\mathrm{T}$ (.55) in this group, so H04 proposing that culture-free texts do not have any significant influence on the listening comprehension of Iranian EFL learners was not rejected.

In other words, the t-value revealed that the four groups performed differently on the posttest which was indicative of the fact that greater cultural familiarity with language listening materials promotes the Iranian EFL learners' listening comprehension.

The results of the study, however, contradict that of Long (1990) in that she observed no significant difference between the familiar and unfamiliar passages for the recognition measure, though the English summaries revealed a higher proportion of correct units for the familiar topic. At the same time, the results of the study contradict the perceptual phase of Bacon's (1992) study in which she found little use of advance organizers during this phase.

\section{Discussion}

According to Sasaki, Yoshinori and Gakuin (1991), two general views exist in relation to culture and materiel designing in ELT. Advocates of the first view believe in teaching English without culture or culturally sterile teaching. Assigning no role to culture in teaching English as a second or foreign language, they reject the direct inclusion of culture in the school curriculum. In Iran, this idea has resulted in the expulsion of culture from the state-school curriculum on the grounds that:

1) Persian culture is a mixture of national and Islamic cultures. National culture is based on old customs and traditions which people follow during the history and Islamic culture is originated from religious beliefs and rules which people try to obey in their every day life.

2) The dominant western culture will be a threat to our local culture. 
3) Teaching western culture may result in cultural conflict.

4) If you teach and emphasize English culture in EFL classes, you may be labeled negatively as a western-oriented or politically-motivated teacher.

On the other hand, supporters of the second view believe in the inclusion of culture in the curriculum, because they believe language and culture are not separable and all language is interpreted in relation to the culture and, therefore, teaching language irrespective of culture is impossible. They believe that language and culture are so interwoven that focusing on one irrespective of the other is very difficult if not impossible. This very notion was somehow approved in the present study. That is, the results indicated that cultural familiarization of the text has a significant effect on listening comprehension. Listeners are expected to achieve the writer's intended meaning by combining existing information with what they listen (Bacon, 1992; Chastain, 1988; Chiang \& Dunkel, 1992; Long, 1990; Markham \& Latham, 1987; Mueller, 1980; Schmidt-Rinehart, 1994).

The familiarization of the terms related to the customs and traditions in the short-term memory contributed to schema activation of the listeners (Alptekin 1981; Schank \& Abelson, 1977). The listeners who listen to the culturally-oriented texts also did not have to deal with unfamiliar terms in it and this resulted in better comprehension since they could process new input in their short-term memory.

According to Anderson and Lynch (2000), successful comprehension in listening takes place when the listener has schematic knowledge, knowledge of the context and systemic knowledge. In the treatment lessons, the participants had the opportunity to deal with key vocabulary items that were presented in the same context as they would hear in the text. This is consistent with previous studies (Caplan-Carbin, 1997; Ervin, 1992; Gatbonton \& Segalowits, 1988; Sadighi \& Zare 2002; Schmidt \& Rinehart, 1994; William \& Thomas, 1991).

Providing the learners with background knowledge as well as systemic knowledge as advocated by Anderson and Lynch (2000) provides learners with the necessary information to facilitate comprehension of an unfamiliar topic. The reason behind this might be that building background knowledge and topic familiarity about the cultural context of listening texts could lead the participants in groups A, B and C to improve their listening comprehension to a significant extent during this study.

Moreover, the results of the present study challenges and rejects Chambers' view (1997) that comprehension as a crucial component of aural proficiency is acquired and emerges naturally and cannot be improved through practice or exposure to language listening materials such as those of culturally-oriented listening texts. According to Chambers, the automatic promotion of listening comprehension develops naturally during any language learning situation. In other words, Chambers emphasizes the point that other language skills and sub-skills can be improved through practice and exposure except listening comprehension.

Based on the results obtained, it seems that the Iranian EFL course books do not adequately prepare students for an intercultural communication due to the fact that they focus excessively on language forms, lack diverse social issues, and do not promote students' awareness of the target language culture. If culture and language are inseparable, then we need to try to teach culture in some kind of systematic way as we try to do with other aspects of language such as grammar and vocabulary. The results indicate that the Iranian EFL course books do not prepare students to cope with the international society. Additionally, the aim of foreign language teaching does not seem to develop the basic competence for mutual communication, using and understanding every day English due to the fact that, in Iran, teaching methods are not directed, as it should be, toward the target language culture.

\section{Pedagogical implications}

Having background knowledge is a key feature of any kinds of listening materials, so language learners wanting to improve their listening comprehension should have greater exposure to two kinds of listening materials: target culture materials and international target culture materials. Through having greater exposure to specific culturally-oriented materials, for example, English culture materials, language learners can improve their listening comprehension.

Background knowledge, cultural familiarity and linguistic complexity are essential linguistic and meta-linguistic features for the enhancement of listening comprehension. Accordingly, having exposure to language materials in which these three features are highly observed can boost listening comprehension development.

Vocabulary recycling is another feature regarding developing any listening materials which is generally supposed to help language learners build up their lexicon over time. Moreover, according to Abu Rabia (1998), language learners can acquire the knowledge, structures, strategies, and vocabulary items they can use in everyday situations through having exposure to culturally-oriented materials. The vocabulary items used in culturally oriented texts are basic to the type of conversations that language learners are likely to encounter in a social situation.

\section{Limitations of the study}

This study endeavored to manifest the effect of cultural familiarity on promoting pre- intermediate language learners' listening comprehension skill. Similar to other studies, this research has its own particular limitations In order to make 
the research move manageably, some limitations were made. In so doing, age and gender were not considered as the intervening variables in the study. Moreover, the second limitation is related to the fact that the participants of the present study were coming from one particular area of the country. Different language teachers throughout the country may have their own methodology in language teaching and consequently language learners may receive relatively different instructions. Therefore, it seems reasonable to deduce that a big nationwide research project is needed to confirm the results of such a study.

\section{Conclusion}

As stated at the beginning of this paper, culture and language are inexorably linked and as such cannot be separated. Numerous authors (Byram 1997; Harumi, 2002; Kramsch 1993) have highlighted the impossibility of teaching English without teaching culture. Savignon and Sysoyev (2002) emphasizing the necessity of teaching culture for EFL learners propose that if it were not English but any other language in the world, then it would be possible to teach the culture with the language; but that is not the same for English as it is a global language. The language of Bulgaria belongs to Bulgarian, the language of Dutch belongs to the Netherlands; but the language of English does not belong to Britain any more. Whether culture is consciously or unconsciously part of the teachers' pedagogic aims, the transmission of culture is unavoidable. The content of what we teach will always be in some way linked to culture, as Tseng (2002) points out "every lesson is about something and that something is culture" (p.20).

\section{References}

Abu-Rabia, S. (1998). Social and cognitive factors influencing the reading comprehension of Arab students learning Hebrew as a second language in Israel. Journal of Research in Reading, 21(3), 201-12.

Aliakbari, M. (2004). The place of culture in the Iranian ELT textbooks in high school level. The Linguistic Journal, 1, $1-14$.

Alptekin, C. (1981). Sociopsychological and pedagogic considerations in L2 acquisition. TESOL Quarterly, 15(3), 275-284.

Anderson, A. \& Lynch, T. (2000). Listening. Oxford: Oxford University Press.

Bacon, S. M. (1992). Phases of listening to authentic input in Spanish: A descriptive study. Foreign Language Annals, 25 , 317-334.

Byram, M. (1997). Teaching and assessing intercultural communicative competence. The Linguistic Journal, 21, 252-274.

Caplan-Carbin, L. (1997). Familiarity and listening comprehension. Retrieved August 2007 from http://webgerman.com/caplan/Portfolio/Caplan/research97.htm

Cele-Murcia, M. (2001). Teaching English as a second or foreign language (3rd ed.).Boston. MA: Heinle \& Heinle.

Chambers, F. (1997). What do we mean by fluency? System, 25(4), 535-544.

Chastain, K. (1988). Developing second-language skills: Theory and Practice ( ${ }^{\text {rd }}$ ed.). New York: HBJ Publishers.

Chiang, Ch. S., \& Dunkel, P. (1992). The effect of speech modification, prior knowledge, and listening proficiency on EFL lecture learning. TESOL Quarterly, 26, 345-374.

Cook, G. (2003). Applied linguistics. Oxford: Oxford University Press.

Ervin, B.K. (1992). Does knowledge of culture and instruction using thematic units affect listening comprehension. Reading Psychology Journal, 12, 43-61.

Gatbonton, E.C. and Segalowitz, N. (1988). Creative automatization: Principles for promoting fluency within a communicative framework. TESOL quarterly, 22(3), 473-492.

Genc. B. and Bada, E. (2005). Culture in language learning and teaching. The Reading Matrix, 5(1), 73-84.

Graves, M., \& Cook, C. (1980). Effects of previewing difficult short stories for high school students. Research on Reading in Secondary Schools, 6, 38-54.

Hao, T. (2000).On factors of influencing English listening teaching and learning. Retrieved Sept. 2008 from http://zhushenhai.anyp.cn.

Harumi, I. (2002). A new framework of culture teaching for teaching English as a global language. RELC Journal, 33(2), 36-57.

Kramsch, C. (1993). Teaching culture in literature in the ESL/EFL classroom. Retrieved Sept. 2008 from http://iteslj.org/Lessons/Plastina-CultureInLiterature. 
Long, D. R. (1990). What you don't know can't help you: An exploratory study of background knowledge and second language listening comprehension. Studies in Second Language Acquisition, 12, 65-80.

Markham, P. L., \& Latham, M. (1987). The influence of religion-specific background knowledge on listening comprehension of adult second language students. Language Learning, 37, 157-170.

Mueller, G. A. (1980). Visual contextual cues and listening comprehension: An experiment. Modern Language Journal, 64, 335-340.

Nunan, D. (1998). Approaches to teaching listening in language classroom. In proceedings of the 1997 Korea TESOL Conference. Taejon, Korea: KOTESOL.

Othman, J. and Vanathas, C. (2004). Topic familiarity and its influence on listening comprehension. The English Teacher, 8, 19-32.

Richards, J. C. (2005). New interchange series. (4th ed.). Cambridge: Cambridge University Press.

Rost, M. (2002). Teaching and researching listening. London, UK: Longman.

Sadighi, F. and Zare, S. (2002). Is listening comprehension influenced by the background knowledge of the learners? A case study of Iranian EFL learners. The linguistics Journal, 1(3), 110-126.

Sasaki, K. Yoshinori, J. and Gakuin, A. (1991). Effects of cultural familiarity on reading comprehension. Language Learning Journal, 33, 183-95.

Savignon, J. S. and Sysoyev, V.P. (2002). Sociocultural strategies for a dialogue of cultures. The Modern Language Journal, 84, 508-524.

Schank, R. \& Abelson, R. (1977). Scripts, plans, goals, and understanding. Reading Research Quarterly, 24, 27-43.

Schmidt-Rinehart, B. C. (1994). The effect of topic familiarity on second language listening comprehension. Modern Language Journal, 78(2), 179-189.

Sharpe, P. J. (2001). How to practice for the TOEFL. (10th ed.).London: Barron's Educational Inc.

Tseng, Y. (2002). A lesson in culture. ELT Journal, 56(1), 11-21.

Tsou, W. (2005). The effects of cultural instruction on foreign language learning. RELC Journal, 36(1), 39-57.

William, C. \& Thomas, M. (1991). Increasing comprehension by activities prior knowledge. ERIC Digests. Retrieved Sept. 2008 from http://www.ericdigests.org/pre-9219/prior.htm.

Table1. Mean scores gained by treatment groups in the pre-tests

\begin{tabular}{l|lll}
\hline condition & Mean & $N$ & Std. Deviation \\
\hline TC & 11.56 & 30 & 1.57 \\
ITC & 10.6 & 30 & 1.76 \\
SC & 10.1 & 30 & 1.72 \\
CF & 10.13 & 30 & 1.72 \\
\hline TOTAL & 42.39 & 120 & 6.77 \\
\hline
\end{tabular}

Table 2. Mean scores gained by treatment groups in the post-tests

\begin{tabular}{l|lll}
\hline condition & Mean & $N$ & Std. Deviation \\
\hline TC & 14.46 & 30 & 1.52 \\
ITC & 13.73 & 30 & 1.82 \\
SC & 13.1 & 30 & 1.72 \\
CF & 10.16 & 30 & 1.71 \\
\hline TOTAL & 51.45 & 120 & 6.77 \\
\hline
\end{tabular}

Table 3. One-Way ANOVA Test Results

\begin{tabular}{l|llllll}
\hline $\begin{array}{l}\text { Dependent } \\
\text { Variable }\end{array}$ & & $\begin{array}{l}\text { Sum of } \\
\text { Squares }\end{array}$ & $d f$. & $\begin{array}{l}\text { Mean } \\
\text { Square }\end{array}$ & F & Sig. \\
\hline $\begin{array}{l}\text { Post-Test } \\
\text { score }\end{array}$ & $\begin{array}{l}\text { Between } \\
\text { Groups }\end{array}$ & 319.41 & 3 & 106.47 & 11.92 & 9.24 \\
& \begin{tabular}{l} 
Within Groups \\
\cline { 2 - 7 }
\end{tabular} & 1035.98 & 116 & 8.9308 & & \\
\cline { 2 - 7 } & Total & 1373.39 & 119 & & & \\
\hline
\end{tabular}


Table 4. Descriptive statistics of the pretest and the posttest of group $\boldsymbol{A}$

\begin{tabular}{l|llll}
\hline tests & $N$ & Mean & $S D$ & t-test \\
\hline Pretest & 30 & 11.56 & 1.57 & 4.02 \\
\cline { 1 - 4 } Posttest & 30 & 14.46 & 1.52 & \\
\hline
\end{tabular}

Table 5. Descriptive statistics of the pretest and the posttest of group $\boldsymbol{B}$

\begin{tabular}{l|llll}
\hline tests & $N$ & Mean & $S D$ & t-test \\
\hline Pretest & 30 & 10.60 & 1.76 & \multirow{2}{*}{3.30} \\
\cline { 1 - 4 } Posttest & 30 & 13.73 & 1.82 & \\
\hline
\end{tabular}

Table 6. Descriptive statistics of the pretest and the posttest of group $\boldsymbol{C}$

\begin{tabular}{l|llll}
\hline tests & $N$ & Mean & $S D$ & t-test \\
\hline Pretest & 30 & 10.10 & 1.72 & 3.42 \\
\cline { 1 - 4 } Posttest & 30 & 13.10 & 1.72 & \\
\hline
\end{tabular}

Table 7. Descriptive statistics of the pretest and the posttest of group D

\begin{tabular}{l|llll}
\hline tests & $N$ & Mean & $S D$ & t-test \\
\hline Pretest & 30 & 10.13 & 1.72 & .55 \\
\cline { 1 - 4 } Posttest & 30 & 10.16 & 1.71 & \\
\hline
\end{tabular}

